\title{
Features of the formation of click beetle complexes in perennial plantings of the Western Caucasus
}

\author{
Valeriy Orlov* \\ Federal State Budgetary Scientific Institution "National Center of Grain named after P.P. Lukyanenko", \\ Krasnodar, 350012, Russia
}

\begin{abstract}
The complexes of click beetles in the perennial plantations of the Western Caucasus are formed at the expense of species from the surrounding (adjacent) biotopes. In the forest zone, the complexes are formed by their similarity to meadow biotopes (biocenoses) with inclusions of dominant species from meadow biotopes of the foothill lane. Agriotes tauricus Heyd., and Drasterius bimaculatus (Rossi) are common species in all lanes and zones of the studied region. Species Agriotes gurgistanus (Fald.), Melanotus fusciceps (Gyll.), Athous Circassiensis Reitt., Agriotes sputator (L.) are most often dominant of elateridocoplex.
\end{abstract}

\section{Introduction}

Intensification and biologization are modern trends in agricultural production. Chemical protection and organic farming as the extreme sides of intensification and biologization, respectively, have created the direction of adaptive crop production based on the use of natural self-regulation mechanisms with the possibility of introducing targeted (often point) control methods into the ecosystem. This approach was especially in demand in areas where the intensification of agricultural production has not yet reached its maximum level [1-3]. The development of this approach, the emergence of various electronic resources in combination and with the availability of technical devices made it possible to raise both space sensing and aerial photography to a new level. Experts have gained access to mobile global resources that allow them to get their position in various databases and use some of the integrated digitized indicators of the environment and phytocenoses for analysis [4-6]. But in this system, the bottleneck was and remains the direct fixation of biological objects, and if the agricultural service is at least able to cope with the identification of widespread diseases and pests, then the appearance of unfamiliar objects, especially when they appear on a massive scale, often causes, if not panic in the region, then very strong concern. This is usually associated with a secretive living species. One of these groups are click beetles (Coleoptera, Elateridae). Although click beetles are a fairly well-studied group for field crop rotations, for perennial crops this knowledge is very fragmentary, or at least not summarized in a system. On the other hand, the study of this group, due to their lesser importance in the

*Corresponding author: elater@mail.ru 
cultivation of perennial crops, is not so popular. The main work on the study of Elateridae in field crop rotations in the territory of the former USSR was carried out in the second half of the last century, and modern work is known only for certain territories [7], which predetermines in the near future the resumption of scientific work of such a plan. It is interesting that now such works have begun to gain popularity in the New World [8-10], especially since the last works in those territories were carried out a long time ago - back in the middle of the last century. In the works of such a plan, it should be borne in mind that the high-quality conduct of such research requires a sufficient number of specialists with narrow qualifications, and there are not enough of them everywhere, because of which the performance of such works at the required level will be held back. The solution to this problem in the diagnosis of harmful objects can be the introduction of molecular genetic analysis into the work. (DNA barcoding). The success and popularity of which in the study of biodiversity is constantly increasing [11-13]. It is especially interesting that for some economically significant species of click beetles it is already possible to use DNA barcoding [14-16].

In turn, the problem of unification received not only a solution, but also new tasks. Thus, the latest information obtained on the basis of molecular genetic analysis revealed new relationships in the phylogeny of various groups, including for the Elateridae. In particular, bioluminescent lampyroids can now be included in the family of click beetles [17]. This fact challenges both the currently existing classification of Elateridae, Lampyridae, Phengodidae, and Rhagophthalmidae, and suggests updating the analytical databases and revising the role of the economically important group of elateridae in various biotopes, including garden and grape cenoses.

If the topic of research and its relevance at first seemed dubious, since there is still enough academic research on the fauna of the region in different groups of animals, and a qualified specialist, having opened work with the fauna of the region of the necessary group, could gather information and recreate, in general terms, its economic significance, then the strengthening of specialization in education in agronomic specialties no longer allows agronomists to interpret information on the fly. In addition, this is aggravated by the commercialization of special literature - now for a simple selection of literature, and for these purposes it is necessary to leaf through dozens of scattered sources, it is necessary to pay for part of the literature unjustifiably. In addition, the author was repeatedly asked a question by experts of various levels and from different regions about the role and economic importance of click beetles in gardens, vineyards and tea plantations. This article is an attempt to explain the mechanism of the formation of the elateride complex in the orchards and vineyards of the Western Caucasus, or, at least, is the popularization of the topic of biodiversity.

\section{Materials and methods}

When defining the tasks, it turned out that the classification of perennial plantations was developed for individual branches of management and for accounting (accounting), and their international unification, adopted in the Russian Federation, is still being developed and is in the phase of reclassification [18].

The author conditionally highlighted, according to the conditions of natural zones and surrounding landscapes, the following planting options:

1. perennial plantations of the steppe zone

2. perennial plantations of foothills and the lower part of the mountain-forest lane of the northern macroslope

3. perennial plantations of the mountain-forest lane of the southern macroslope

4. perennial plantations of the upper part of the mountain forest lane 
Our observations in the western Caucasus show the presence of various types of perennial fruit plantations. Since many of them are removed from the official framework of agricultural production, since some of them exist as unused gardens, or as gardens turned into forests, or as small-sized plantations of fruit crops, but their study allows a more complete assessment of the direction of succession processes, we correlated them with the above conditional scheme. Biotopes with the participation of other perennial plantations with shorter periods of existence are not discussed in the work.

The studies were carried out using traditional entomological methods [19-23]. The following techniques were used: soil excavations, manual collection of insects, collection of insects using an entomological net, an entomological umbrella, various types of traps (Barbera soil, light, food, pheromone), analysis of rotten wood. Photoelectors were also used to collect insects.

\section{Results and discussion}

Changes in the phyto-environment in the garden and in vineyards in the initial periods of the formation of plots in different economic entities usually occur in different ways. So, with intensive care of a young orchard or vineyard, the conditions are not only comparable to those on field crops, but sometimes even more extreme, which from the immediate environment of biotopes may be comparable to degraded soils on the slopes of large ravines and along the banks of streams. In one of our works, in the catena across the Psekups riverbed, changes in the distribution of click beetle species were studied, where it was shown that in the foothill belt such areas are inhabited by species from the genus Drasterius Esch. and Agriotes Esch. In turn, a number of farms, while saving on soil cultivation, allow the entire or part of the site to be tinned, which creates conditions close to meadow biotopes. Insect species migrating from adjacent natural biotopes often have great opportunities for dispersal in such close enough conditions free from competing species.

In orchards and vineyards, the pesticide load for most of the species of click beetles is significant only when the time of insecticidal treatments coincides with the periods of flight of beetles. In most species, seasonal flight coincides with the flowering periods of crops, especially in pollinator species.

In perennial plantations in the steppe zone, a complex is formed, consisting mainly of dominant species in the steppe areas of this zone. Among the soil-living species, the dominant species are Agriotes gurgistanus (Fald.) and Melanotus fusciceps (Gyll.). In the south of the steppe zone, Agriotes tauricus Heyd becomes dominant. In the soils of vineyards, in addition to the listed species, Drasterius bimaculatus (Rossi) is usually a mass species. In conditions close to riverbeds, watercourses, and on flooded soils, Agriotes ponticus Step and A. sputator (L.) are often the main species in all field crop rotations and adjacent plantings, but their distribution in the areas is usually focal. Species of the genus Aeoloderma Fleut. and Aeolosomus Dolin. can be a typical component of ampelocenosis on flooded soils. As pollinators in old tree plantations, species of the genus Ampedus Dej and Cardiophorus Esch. are common.

In the perennial plantations of the foothill lane on meadow soils, a species-rich complex of elaterides is formed. Among the dominant species, the soil contains Agriotes tauricus Heyd., Athous. Circassiensis Reitt., Agriotes sputator (L.). Drasterius bimaculatus (Rossi). Selatosomus latus (Fabr.) are sometimes quite typical components of the complex. As a pollinator, Limonius minutus (L.) is common here, and surrounded by natural woody vegetation, species from the genus Ampedus Dej and Cardiophorus Esch. join pollination.

The complexes of species of click beetles in perennial plantations of the lower part of the mountain-forest lane of the northern and southern macroslopes have noticeable differences. In the plantations located on the northern macroslope, complexes of click beetles 
that are quite close to the foothill biotopes are formed. In the gardens of the mountain forest lane, Agriotes tauricus Heyd., A. starcki Schw., Athous circassiensis Reitt., Drasterius bimaculatus (Rossi), Agriotes sputator (L.) are common in the soil. In the soils of the southern macroslope, the composition of the complexes, in addition to A. tauricus Heyd., $A$. starcki Schw., and Drasterius bimaculatus (Rossi), is complemented by such species as $A$. infuscatus Desbr., A. brevis Cand., and A. bogatschevi Dol is common in their subtropical part. Representatives of many genera are noted here as pollinators: Ampedus Dej., Athous Esch., Cardiophorus Esch., Melanotus Esch., Pseudocrepidophorus Dol. et Ag. and et al. On tea plantations and on hazelnut plantations, only A. tauricus Heyd. were collected in the soil, but collections of imagos showed a richer composition of species.

At the heights that are maximum for the growth of fruit crops, the composition of the complexes of click beetles is poorly studied. In the Absheron District, Agriotes obscurus (L.) and Athous circassiensis Reitt were found in a garden at an altitude of $1200 \mathrm{~m}$ above sea level. - species typical for meadow biotopes of this altitudinal lane.

The study of abandoned agrocenoses of field crops, perennial plantings shows that, as an agrocenosis, these areas exist from 1 to 3 years in the case of field crops and up to ten or more years with the predominant participation of woody and shrub plants such as tea, hazelnuts, apple trees, pears, grapes.

The formation of complexes of click beetles in perennial plantations strongly depends on the composition of species in the surrounding biotopes. As a rule, more plastic species from among the serious pests of field crops dominate.

In addition, it was revealed that the problem of unification of biodiversity data received new tasks for Elateridae, such as updating analytical databases and revising the role of this economically important group in various biotopes, including in garden and grape cenoses.

\section{References}

1. M. Akhmetzyanov, I. Talanov, Vestnik of Kazan State Agrarian University, 14, 10-14 (2020) http://doi.org/10.12737/2073-0462-2020-10-14

2. N.P. Bakaeva, O.L. Saltykova, M.S. Prikazchikov, BIO Web Conf., 27, 00074 (2020) https://doi.org/10.1051/bioconf/20202700074

3. N.A. Voronkova, I.A. Bobrenko, N.M. Nevenchannaya, V.I. Popova, IOP Conf. Ser: Earth Environ. Sci., 548, 022071 (2020) http://doi.org/10.1088/1755-1315/548/2/022071

4. O. Yermolaev, Eurasian Soil Sci., 50(1), 118-131 $\quad$ (2017) http://doi.org/10.1134/S1064229317010070

5. E.A. Skvortcov, E. Skvortsova, I. Sandu, G. Iovlev, Economy of region, 14(3), 10141028 (2018) https://doi.org/10.17059/2018-3-23

6. S. Gilev, A. Zargaryan, E. Nesterova, Advances in Intelligent Systems Research, 167, 8992 (2019) https://doi.org/10.2991/ispc-19.2019.20

7. A.G. Koval, O.G. Guseva, Entmol. Rev., 99, 744-752 https://doi.org/10.1134/S0013873819060046

8. M. Traugott, C. Benefer, R. Blackshaw, W. Van Herk, R. Vernon, Annual Review of Entomology, 60(1), 313-334 (2014) http://dx.doi.org/10.1146/annurev-ento-010814021035

9. W.G. Van Herk, R.S. Vernon, S. Acheampong, J.K. Otani, K. Uloth, J. Asia-Pacific Entomol. (2021) https://doi.org/10.1016/j.aspen.2021.06.001

10. W.G. Van Herk, R.S. Vernon, T.J. Labun, M.H. Sevcik, T.D. Schwinghamer, Environ. Entomol., 50(3), 663-672 (2021) https://doi.org/10.1093/ee/nvab006

11. A. Campbell, A. Lawrence, C. Hudspath, M. Gruwell, Insects, 5(3), 528-538 (2014) http://doi.org/10.3390/insects5030528 
12. F. Zhu, C. Raman, P. Pelsoi, E. Park, B.B. Patnaik, M. Sugumaran, B. Pittendrigh, F. Noriega, Z. Gui, A. Ejiofor, In: R. Chandrasekar, B.K. Tyagi, Z. Gui, G.R. Reeck (eds) Short Views on Insect Biochemistry and Molecular Biology, 3-56 (Academic Publisher, 2014)

13. B. Deák, B. Tóthmérész, O. Valkó, P. Török, B. Sudnik-Wójcikowska, I. Dembicz, I.I. Moysiyenko, T.M. Bragina, I. Apostolova, N.I. Bykov, Biodivers.Conserv., 25 (12), 2473-2490 https://doi.org/10.1007/s10531-016-1081-2

14. K. Staudacher, P. Pitterl, L. Furlan, P.C. Cate, M. Traugott, Bull. Entomol. Res., 101, 201-210 (2011) https://doi.org/10.1017/S0007485310000337

15. T. Han, W. Lee, S. Lee, I.G. Park, H. Park, PLoS ONE, 11(2), e0148602 (2016) https://doi.org/10.1371/journal.pone.0148602

16. T.M. Bragina, M.A. Bobrenko, M.M. Rulyova, Vestnik KGPI, 2(58), 61-67 (2020) https://repo.kspi.kz/handle/123456789/3696

17. H.B. Douglas, R. Kundrata, A.J. Brunke, H.E. Escalona, J.T. Chapados, J. Eyres, R. Richter, K. Savard, A. Ślipiński, D. McKenna, J.R. Dettman, Biology, 10(6), 451 (2021) https://doi.org/10.3390/biology10060451

18. Agriculture: Bearer Plants. Proposed amendments to IAS 16 and IAS 41 (IFRS, 2013) https://www.ifrs.org/content/dam/ifrs/publications/exposure-drafts/english/2013/edagriculture-bearer-plants-proposed-amendments-to-ias-16-and-ias-41-.pdf

19. V.B. Golub, M.N. Tsurikov, A.A. Prokin, Collections of insects: collecting, treatment and keeping of materials (Association of scientific editions KMK, Moscow, 2012)

20. M.L. Ferro, C.E. Carlton, The Coleopterists Bulletin, 65(2), 115-124 (2011) http://dx.doi.org/10.1649/072.065.0202

21. T.A. Catanach, In: Silvy NJ (Ed.) The Wildlife Techniques Manual Research, 1 (7th edn), 336-348) (The Johns Hopkins University Press, Baltimore, MD, 2012)

22. M.L. Ferro, M. Summerlin, ZooKeys, 861, 145-156 https://doi.org/10.3897/zookeys.861.32347

23. J.D. Whitman, D. Yanega, C.B.G. Watson, V.W. Strode, In: Yong WH (Ed.) Biobanking: Methods and Protocols. Methods in Molecular Biology, 1897, 163-189) (Humana Press, NY, 2019) https://doi.org/10.1007/978-1-4939-8935-5_17 